\title{
Flow-Cytometric DNA Content and S-Phase Fraction Values as a Prognostic Factor on Nasopharyngeal Cancer - A Preliminary Report
}

\author{
S. Gondhowiardjo*, R. Susworo*, S. B. Kresno**, S. Hartini**, A. Roezin***, A.N. Kurniawan ****
}

\begin{abstract}
Abstrak
Kandungan DNA inti sel dan aktivitas proliferasi sel telah diketahui berperan sebagai faktor prognostik beberapa kanker, seperti kanker payudara, prostat, dan serviks uteri; tetapi untuk karsinoma nasofaring (KNP), belum diketahui. Penelitian pendahuluan ini menggunakan pemeriksaan flow-cytometry yang relatif sederhana, cepat, lebih akurat dan lebih objektif dibandingkan metode lainnya. Pemeriksaan terhadap 24 KNP tak terdiferensiasi dari 25 spesimen biopsi KNP memperlihatkan adanya distribusi luas nilai-nilai SPF (4,2\% - 44,8\%), pola ploidi (26\% dan 74\% untuk diploid dan aneuploid), serta indeks DNA (0.75-2.72). Penelitian lebih lanjut mengenai hubungan parameter-parameter ini dengan respons radiasi, local and distant control, serta angka kelangsungan hidup masih berlangsung.
\end{abstract}

\begin{abstract}
It is known that the DNA content of the nuclei and proliferation activity can serve as useful prognostic factors in a variety of neoplasms, such as cancer of the breast, prostate, and cervical uterine. However, there is still no clear data about this correlation in the nasopharyngeal cancer (NPC). Flow-cytometric analysis provides an accurate, more objective, rapid and relatively simple examination, compared with other techniques. Our preliminary results of 24 undifferentiated carcinoma out of 25 NPC biopsy specimens demonstrated that there were wide distributions of SPF value $(4.2 \%-44.8 \%)$, ploidy pattern $(26 \%$ vs $74 \%$ for diploid and aneuploid respectively), and DNA index value (0.75-2.72). Further study analyzing the responsibility all of those parameters to the radiation response, local and distant control, and survival rate is still underway.
\end{abstract}

Keywords : DNA content, proliferation activity, DNA index, ploidy pattern and S-phase fraction, PCNA, KI-67.

The prognostic indicators of head and neck tumors are largely determined by the combination of morphologic-diagnosis and clinical stage of the tumor. ${ }^{2,4}$ In fact, despite the improvement in surgical and radiotherapy techniques combined with chemotheraphy, these tumors continue to have a fatal outcome in about half of the cases. ${ }^{1}$ Accurate prediction of the biologic behavior of malignant neoplasm is an important factor in determining patient management and the design of clinical therapeutic trial. ${ }^{2}$

Transformation of normal cells into neoplastic growth subsequently is associated with changes in cell behavior. ${ }^{3}$ Cell kinetics, as one aspect of the cellular

Departments of Radiotherapy ${ }^{*}$, Clinical Pathology**, Ear-Nose and Throat ${ }^{* * *}$. Anatomical Pathology ${ }^{* * *}$, Faculty of Medicine. University of Indonesial Cipto Mangunkusumo Hospital, Department of Clinical Pathology, Dharmais Cancer Hospital, Jakarta, Indonesia behavior, can be represented by several proliferation parameters such as thymidine labeling index (TLI), cytometric or flow-cytometric DNA content and Sphase fraction (SPF) values, $T$ potential doubling time ( $T$ pot) by the bromo-deoxyuridine (thymidine analog), proliferating cell nuclear antigen (PCNA), and also Ki 67 fractions. ${ }^{3-5}$ Whereby, cancer treatment modalities such as chemo and radio-therapies are potentially only effective in a certain cellular proliferation phase. ${ }^{6}$

In Indonesia, nasopharyngeal cancer (NPC) is the most frequently found malignancy in head and neck region. Moreover, it was the third highest from all malignant diseases treated by radiation. Most of the NPC patients are males within the productive ages, who seek medical help at the locally advanced stage, which is wellknown to have a high incidence of local failure after treatment, which subsequently causes mortality. 7,8

Surgical intervention of the NPC is hampered by the difficulties of the tumor localization. ${ }^{9-11}$ Moreover, up 
to now, chemotherapy does not show a good result. Thus, radiation remains the treatment of choice. 9,11 However, in order to increase the radiation result, a lot of efforts are still needed, such as changes in fractionation method of irradiation which should be based on cellular proliferation activity. ${ }^{9}$

Since there is no clarification concerning the role of cell kinetic and DNA content as predictor of radiation response in the NPC, we conducted an investigation to explore the potential role of these parameters in relation to the existing malignancy indicators.

The first part of this study will be dealing with the relationship between proliferation activity and DNA content values yield through flow-cytometric analysis, i.e., the $S$ phase fraction (SPF) value, DNA index and ploidy pattern of the NPC cells as compared to WHO histo-pathologic grading. The second part will highlight the relationship of these values as compared to the clinical radiation response, local control and survival of the patients in order to establish the role of this parameters as a prognostic indicator (Figure 1).

\section{METHODS}

Biopsy specimens obtained from suspected NPC patients were directly placed in Eppendorf tube consisting $70 \%$ alcohol and stored in $4^{\circ} \mathrm{C}$ until processed.
Specimens were fragmented either manually or enzymatically by using $1 \mathrm{ml} 0.5 \%$ pepsin (Sigma, St. Louis, USA) to form a single cell suspension. After centrifuging the suspension at $1.500 \mathrm{rpm}$ for 5 minutes at $4^{\circ} \mathrm{C}$ and removal of the supernatant, the suspension was washed twice with $1 \mathrm{ml}$ phosphat buffered saline solution. Then, it was incubated with $1 \mathrm{ml}$ propidium iodide (PI, Sigma, St. Louis, USA) working solution for 30 minutes. The PI working solution was prepared earlier, by mixing $10 \mathrm{ml}$ PBS solution with $300 \mu \mathrm{l}$ PI stock solution, $1 \mathrm{mg}$ RNAase (Sigma, St. Louis, USA) and $25 \mu \mathrm{l}$ Triton X-100.

The cell suspension was filtered with 40 micron nylon mesh prior to flow cytometric analysis. The automatic measurement of the SPF value, DNA index and ploidy pattern were done by using the "cell fit program" from the Beckton-Dickinson flow-cyto-meter facs scan.

SPF value indicated the number of cellular fractions during the $S$ phase within the population of tumor cells. The ploidy pattern consisted of an-euploid, diploid, and tetra-ploid. An-euploid pattern was judged when the abnormal DNA content was distributed beyond the $10 \%$ deviation-range of the DNA content within the normal cells. Abnormal DNA content deviation-range which was located two times beyond the normal value was defined as tetra-ploid. The ratio between the abnormal DNA content of the tumor as compared to the normal cell was named DNA index.

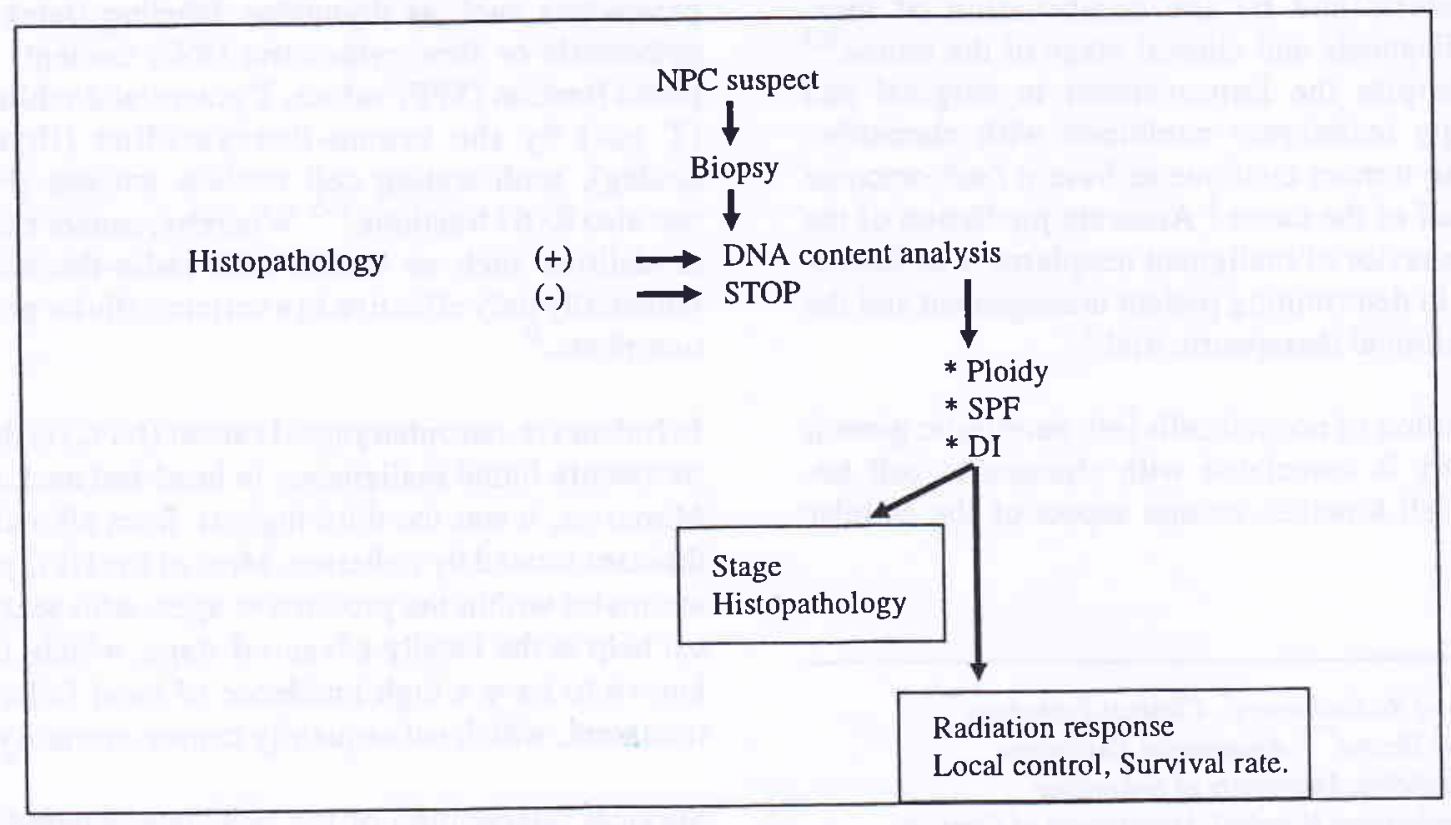

Figure 1. Flow of the study. 
Histopathologic data were obtained from the medical records and were done by the Department of Pathology, Faculty of Medicine, University of Indonesia. No effort was done to re-evaluate the histopathologic diagnosis by the respective pathologist.

\section{Statistical description and analysis}

The frequency distribution and other descriptive statistics (mean, median, range and SD) were calculated with the SPSS program, after all the SPF, DNA index values, ploidy pattern and the histologic pattern of the NPC were compiled into a computerized data file.

Later on all those variables means and the end point values of this study such as the radiation response, local and distant control, and 2 years survival rate were tested using the two tailed student-t or chi-square test. The linear correlation between bi-parameter variables was estimated by Pearson product limit test.

\section{RESULTS}

\section{DNA content}

Figure 2 shows the FCM DNA content analysis histogram from the alcohol fixed specimen biopsy of NPC patients, which is separated according to method of making the single cell suspension, manually or enzimatically. It seems that no different histograms were presented using these two kinds of technique.

\section{Histopathologic diagnosis}

There were 25 biopsy NPC specimens available for this study. The average age of the patients was 41.6 years (ranged between 12-65 years), $68 \%$ of them were male. Twenty three out of the 25 NPC patients were classified as stage IV (AJC/UICC 1992), and the rest of them were recurrent cases.

One out of the 25 specimens was morphologically judged as squamous cell carcinoma (SCC) type, while the rest were classified as undifferentiated cancer (WHO histopathological classification).

\section{SPF values}

Since clinically undifferentiated NPC has shown a wide variation in treatment out-come, we examined the SPF value as the simplest objective proliferation parameter. Our study demonstrated that the SPF values were distributed between $4.2 \%-44.8 \%$ from the

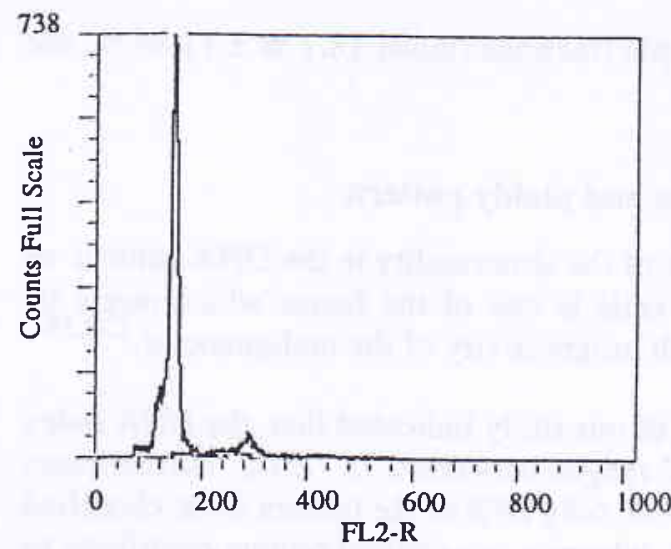

(a)

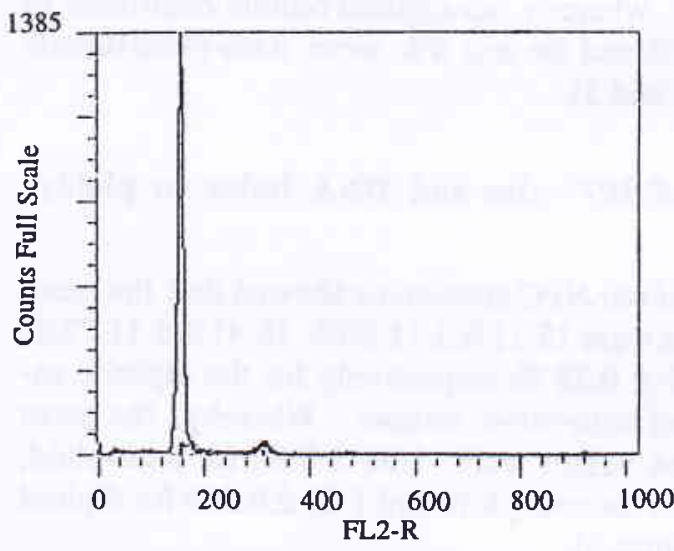

Figure 2. Flow-cytometric DNA content analysis a. single cell suspension was done manually b. single cell suspension was done enzimatically

Table 1. Result of flow-cytometric DNA content analysis on 25 of NPC patients

\begin{tabular}{|c|c|c|c|c|c|}
\hline No & Stage & Histopathology & $\operatorname{SPF}(\%)$ & DI & PLOIDI \\
\hline 1 & Residive & undiff.ca & 25.4 & 1.72 & $\mathbf{a}$ \\
\hline 2 & $\operatorname{tln} 3 \mathrm{~m} 0$ (IV) & undiff.ca & 04.2 & 1.12 & $\mathbf{a}$ \\
\hline 3 & $t \ln 3 \mathrm{~m} 0$ (IV) & undiff.ca & 05.4 & 1.02 & d \\
\hline 4 & $14 \mathrm{n} 3 \mathrm{~m} 0$ (IV) & undiff.ca & 26.1 & 0.75 & $\mathbf{a}$ \\
\hline 5 & $12 \mathrm{n} 3 \mathrm{~m} 0$ (IV) & undiff.ca & 06.5 & 1.05 & d \\
\hline 6 & $14 \mathrm{n} 3 \mathrm{~m} 0$ (IV) & undiff.ca & 17.7 & 1.08 & d \\
\hline 7 & $\tan 3 \mathrm{~m} 0$ (IV) & undiff.ca & 14.3 & 1.17 & a \\
\hline 8 & $\mathrm{t} 4 \mathrm{n} 3 \mathrm{~m} 0$ (IV) & undiff.ca & 19.2 & 1.30 & $\mathbf{a}$ \\
\hline 9 & $13 \mathrm{n} 3 \mathrm{~m} 0$ (IV) & undiff.ca & 05.3 & 0.82 & a \\
\hline 10 & $\operatorname{tln} 2 \mathrm{~m} 0(\mathrm{IV})$ & undiff.ca & 11.5 & 1.06 & d \\
\hline 11 & $12 \mathrm{n} 2 \mathrm{~m} 0(\mathrm{IV})$ & undiff.ca & 08.8 & 1.40 & $\mathbf{a}$ \\
\hline 12 & $t \ln 3 \mathrm{~m} 0$ (IV) & undiff.ca & 08.6 & 1.10 & a \\
\hline 13 & $\tan 3 \mathrm{~m} 0$ (IV) & undiff ca & 25.4 & 1.70 & a \\
\hline 14 & $\operatorname{tln} 2 \mathrm{~m} 0$ (IV) & undiff ca & 32.8 & 1.96 & $t$ \\
\hline 15 & $\tan I \mathrm{~m} 0$ (IV) & undiff ca & 09.0 & 1.86 & $\mathbf{a}$ \\
\hline 16 & t4n I m0 (IV) & undiff ca & 10 & 2.22 & a \\
\hline 17 & t $4 \mathrm{n} 2 \mathrm{~m} 0$ (IV) & undiff ca & 13.8 & 2.72 & a \\
\hline 18 & $t \ln 2 \mathrm{~m} 0$ (IV) & undiff ca & 32.4 & 2.00 & $\mathrm{t}$ \\
\hline 19 & $\mathrm{t} 2 \mathrm{n} 2 \mathrm{~m} 0$ (IV) & undiff ca & 44.8 & 0.75 & $\mathbf{a}$ \\
\hline 20 & $\operatorname{tIn} 3 \mathrm{~m} 0$ (IV) & undiff ca & 37.6 & 1.03 & d \\
\hline 21 & Residive & undiff ca & 15.0 & 1.65 & a \\
\hline 22 & $t \ln 2 \mathrm{m0}$ (IV) & SCC & 19.9 & 0.70 & $\mathbf{a}$ \\
\hline 23 & $\mathrm{t} 2 \mathrm{n} 2 \mathrm{~m} 0$ (IV) & undiff $c a$ & 42.2 & 0.70 & a \\
\hline 24 & $t \ln 3 m 0$ (IV) & undiff ca & 21.0 & 0.75 & $\mathbf{a}$ \\
\hline 25 & $\mathrm{t} 2 \mathrm{n} 2 \mathrm{mo}$ (IV) & undiff ca & 05.2 & 1.33 & $\mathbf{a}$ \\
\hline
\end{tabular}


whole sample fractions (mean $18.7 \% \pm 11.84 \%$, see Figure 3).

\section{DNA index and ploidy pattern}

The degree of the abnormality in the DNA content of the tumor cells is one of the factor which might be related with progressivity of the malignancies. $2,12,13$

The result of our study indicated that the DNA index of the NPC ranged between $0.75-2.72$. Furthermore, we found that only $24 \%$ of the tumors were classified as diploid, whereby an-euploid tumors contribute as high as $68 \%$ and the rest $8 \%$ were tetra-ploid tumors (Figures 4 and 5).

\section{Relation of SPF value and DNA index to ploidy pattern}

Analysis of our NPC specimens showed that the mean SPF values were $15.11 \% \pm 11.86 \%, 18.41 \% \pm 11.72 \%$, and $32.6 \% \pm 0.28 \%$ respectively for the diploid, aneuploid and tetra-ploid tumors. Whereby, the mean DNA index values were $1.98 \pm 0.02$ for tetra-ploid, $1.17 \pm 0.75$ for aneuploid and $1.03 \pm 0.049$ for diploid tumor (Figure 6).

Although it is not yet clear, evidence indicated that diploid pattern and a lower SPF value were related to a better prognosis of the tumor. $2,12,13$

\section{DISCUSSION}

The methods of cell proliferation kinetic assessment are usually carried out by the following procedures: auto-radiographic determination of the thymidinelabelled cells, estimation of the DNA contents distribution through cytometric or flow-cytometric machine and detection of bromo-deoxyuridine-labelled cells using monoclonal antibody through immuno-histochemistry method or flow-cytometric analysis. ${ }^{3-5}$

Flow-cytometric DNA contents analysis provides the simplest technique with more quantitative, objective, and rapid measurements of the cyto-kinetic or proliferation rates of the tumor as compared to the other cellular proliferation examination measurements. This machine-dependent, automatic cellular assessment involving a large number of cells, thus, it will subsequently raise the accuracy of the measurement and the objectivity of the analysis. Moreover, it also serves double purpose, namely to detect the nonploid tumor stem-lines and to assess their proliferation by measuring the SPF value. ${ }^{3,4,13}$ This information has been proven to be useful in supplementing the clinical and pathologic classification of several malignant diseases. ${ }^{13,14}$

Recently, a technique to obtain a single cell suspensions from paraffin embedded tissue, formaldehyde or alcohol fixed specimens was described and proved to be successfully effective in examining the DNA contents value through flow-cytometric analysis. ${ }^{13,15-18}$ This method certainly open a chance for an examination of various types of malignancies in either retrospective or in prospective ways.

Accumulating evidence supports the claim that detection of G1 DNA content in tumor cells, in most cases, is a reliable marker of malignancy. Moreover, the proportion of DNA abnormality (DNA Index) and, or DNA proliferation activities (SPF) might reflect the degree of malignancy and its biological behavior. ${ }^{1,5,13,15}$

In this present study, we used the prospective study to analyze DNA content value and proliferative activity of NPC in relation to the treatment outcome.

The NPC single cell suspension was made from an alcohol fixed biopsy specimens, while Johnson et al. ${ }^{13}$ used paraffin-block specimens for various epidermoid head and neck tumor. However, our results were relatively similar in view of mean and distribution ranges $(18.7 \%, 4.2-44.8 \%$ versus $19 \%, 4-45 \%$ and $1.2,0.75-$ 2.72 versus $1.42,0.7-3.5$ respectively for SPF value and DNA index). Moreover, this SPF values were higher than those observed in the other malignancies, such as breast, lung, uterine, cervical and colon (12$15 \%)$. Thus, we were confined that our techniques were reliable.

SPF values indicate the proportion of within the tissue which is actively synthesizing its DNA, and could be thought to be the proliferation status of the tumor.

Although microscopic-based morphology detection and classification of malignant diseases have undergone progressive development in order to achieve accurate diagnosis and sub-classification of human neoplasm, ${ }^{3}$ and cellular differentiation or histo-morphology of the tumors have long been regarded as an important factor related to the natural history and treatment response, ${ }^{18}$ there has been uncertainty toward its reliability. This is particularly true when it is used to predict some biological behaviors such as growth or metastatic capability or therapeutic responses of solid tumors. ${ }^{13}$ It is known that a single histologic-based 


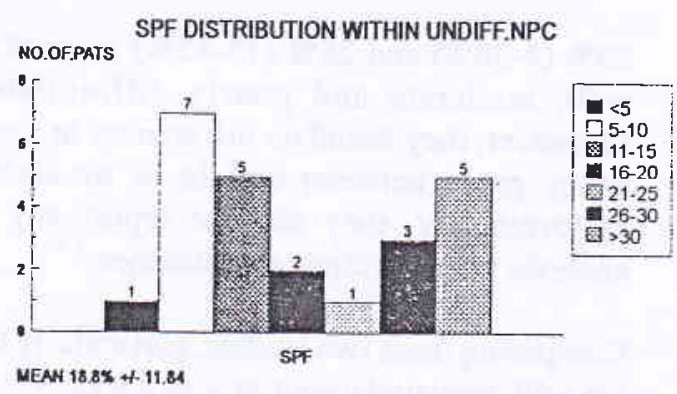

Figure 3. Dsitribution SPF value within unfifferentiated NPC.

DNA INDEX VALUES WITHIN UNDIFF.NPC MO.OF PATS

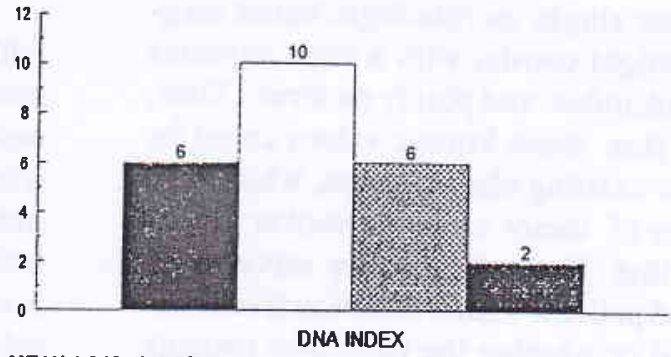

Figure 4. Distribution of DNA index within undifferentiated NPC.

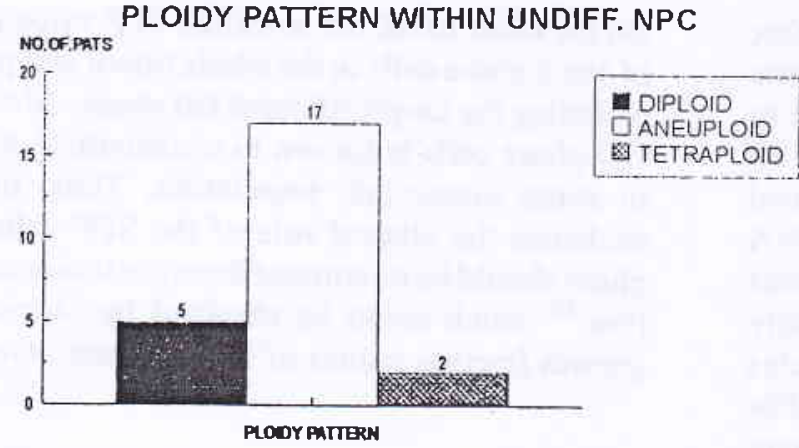

Figure 5. Distribution of Ploidy pattern within the undifferentiated NPC.

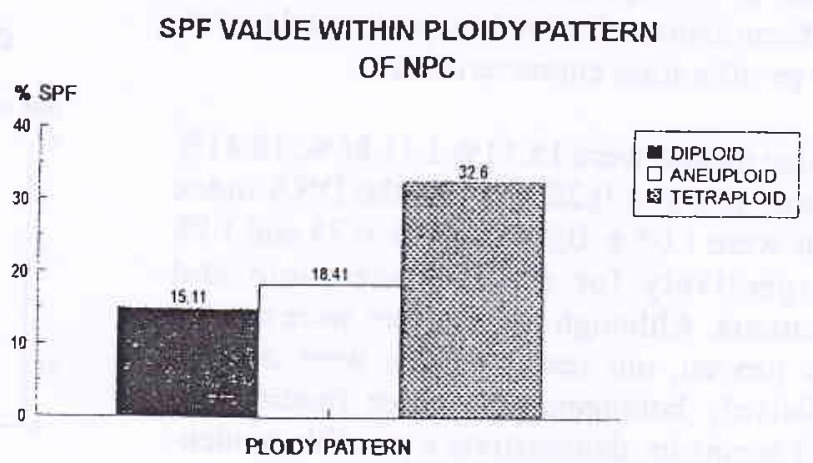

Figure 6. Distribution of SPF value within the ploidy pattern of NPC. 
diagnosis can be associated with a wide range of treatment outcomes. ${ }^{4}$ A unique characteristic of the NPC behavior, which is generally accepted by most clinicians, is that the anaplastic (un-differentiated) NPC will have a better prognosis as compared to the well differentiated types. ${ }^{9}$ However, this phenomenon is not entirely true, since there were radiation response differences among the similar conditions of NPC patients.

This latter observation might be due to differences in the cellular kinetic behavior amongst the NPC patients. This was confirmed with the present study which clearly showed that one single morphologic-based diagnosis of the NPC might consist with a wide varieties of SPF values, DNA index and ploidy patterns. Thus, we have expected that these kinetic values could be used to enhance the existing classification, which will reflect the behavior of tumor cells. Moreover, it was also anticipated that these values may serve as an indicator in selected patients which radiation fractionation should be used or whether the particular patients need a more energetic treatment such as adjuvant treatments, and the use of radio-sensitizer agents. $9,16,17$

A SPF value which was higher than $20 \%$, DNA index higher than 1.5 and an-euploid or tetra-ploid patterns were suggested to have a worse treatment response in other types of malignancies. ${ }^{13}$ In view of the SPF value, five $(20 \%)$ of our patients could be assigned into that group, while $33 \%$ patients showed a DNA Index higher than 1.5 . Furthermore, $76 \%$ of the cases had an-euploid or tetra-ploid patterns. It was clearly seen that there was a wide variation of DNA index $(0.75-2.72)$, Ploidy pattern and SPF values $(4.2 \%$ $44.8 \%$ ) within the relatively homogenous undifferentiated NPC. This concept has also been noted by Dische $^{18}$ that in the squamous cell carcinomas, the cellular differentiation observed is quite unrelated to the cellular proliferation characteristics.

The SPF value means were $15.11 \% \pm 11.86 \%, 18.41 \%$ $\pm 11.72 \%$ and $32.6 \% \pm 0.28 \%$, while the DNA index value means were $1.03 \pm 0.049,1.17 \pm 0.75$ and 1.98 \pm 0.02 respectively for diploid, aneuploid and tetraploid tumors. Although these values were not yet statistically proven, our results which were derived from a relatively homogeneous source (undifferentiated NPC) seems to demonstrate a possible tendency, suggested that there was a relationship between SPF value and the DNA index with the ploidy pattern.

Johnson et al ${ }^{13}$ reported that the SPF values of various epidermoid head and neck tumors were $19 \%(5-40 \%)$,
$20 \%(4-38 \%)$ and $26 \%(13-45 \%)$ respectively for the well, moderate and poorly diffrentiated tumors. Moreover, they found no differences in view of malignancy grade between diploid or un-diploid pattern. Unfortunately, they did not report any correlation analysis with the clinical outcomes. ${ }^{13}$

Comparing these two studies, particularly in the poorly (un)-diffrentiated tumor group, it was clearly seen that our SPF value was lower $(18.7 \%, 4.2 .-44.8 \%)$. This differences might in part explain why the undifferentiated NPC has a better prognosis as compared to the other type of malignancies.

Although Chauvel ${ }^{1}$ showed that cell proliferation kinetics showed significant role in predicting the disease outcome in the head and neck cancer, however, whether those hypothesis (higher SPF value, DNA index and ploidy pattern) are valid as a prognostic indicator for the NPC are still unknown. Furthermore, it is also not yet known, which parameter is the most related to the local, distant controls of the diseases and the survival rates. We are expecting that the second part of our study could clarify this issue.

On the other hand, the so-called SPF value is the ratio of the $\mathrm{S}$ phase cells in the whole tumor cell population, including the un-ploriferated G0 phase. Moreover, the GO phase cells is known to contribute as a large part in some tumor cell population. Thus, in order to enchance the clinical role of the SPF value, the GO phase should be eliminated from the tumor cell population, ${ }^{19}$ which could be obtained by accounting the growth fraction values of tumor tissue. Growth frac-

\section{DNA INDEX VALUES WITHIN PLOIDY PATTERN OF NPC}

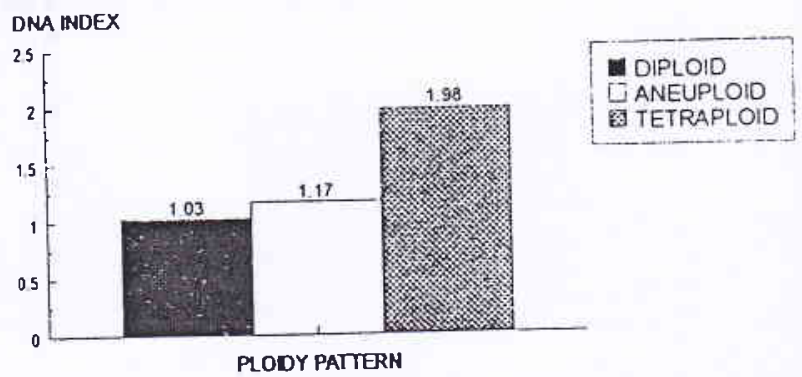

Figure 7. Disttributin of DNA index value within the ploidy pattern og NPC. 
tion value which can be measured by Ki67 and PCNA techniques recognizes all phases of the cell cycles, except the GO phase. $3,4,20,21$

We propose the name of this new value as the proliferating SPF (p-SPF) value, which measures only the SPF value of the proliferating cell phase (G1, S, $\mathrm{G} 2$ and $\mathrm{M}$ ). Further investigation to prove whether this p-SPF value has a greater correlation to the radiation response in a clinical setting is underway.

\section{REFERENCES}

1. Brooks DJ, Garewal HS. Measures of tumor proliferative activity. Int J Clin Lab Res 1992;22:196-200.

2. Naus GJ, Zimmerman RL. Prognostic value of flow cytometric DNA content analysis in single treatment stage IB-IIB squamous cell carcinoma of the cervix. Gynecol Oncol 1991;43:149-53.

3. Chauvel P, Courdi A, Gioanni J, Vallicioni J, Santini, Demard F. The labelling index: a prognostic factor in head and neck carcinoma. Radiother Oncol 1989;14:231-7.

4. Larsen JK. General review cell proliferation: Analysis by flow-cytometry. Nouv Rev Fr Hematol 1992;34:317-35.

5. Tubiana M, Courdi A. Cell Proliferation kinetics in human solid tumors: relation to probability of metastatic dissemination and long-term survival. Radiother 1989;15:1-8.

6. Withers HR. Biologic basis of radiation therapy. In: Perez AC, Brady LW, eds. Principles and practice of radiation oncology. Philadelphia: JB Lippincott Co, 1992; 64-96.

7. Susworo. Kombinasi radiasi eksterna dan intrakaviter: alternatif pengobatan karsinoma nasofaring yang responsif terhadap radiasi. Disertasi. Jakarta: Universitas Indonesia, 1990.

8. Dir-Jen Pelayanan Medik-Departemen Kesehatan R.I., Badan Registrasi Kanker Ikatan Ahli Patologi Indonesia, Yayasan Kanker Indonesia. Data histopatologik kanker di Indonesia tahun 1989.
9. Perez CA. Nasopharynx. In: Perez CA, Brady LW, eds. Principles and practice of radiation oncology. Philadelphia: JB Lippincott Co, 1992:617-43.

10. Rahima M, Rakoowsky E, Barzilay J, Sidi J. Carsinoma of the nasopharynx. Cancer 1986;58:843-9.

11. Pee ZE, Gun LP, Long CK. Radiation therapy of nasopharyngeal cancer: prognostic factors based a 10-year follow-up of 1302 patients. Int J Radiat Oncol Biol Physiol 1989;16:301-5.

12. Dressler LG, Larry MA, Seamer MT, Owens MA, Clark GM, Mc Gure WL. DNA flow cytometry and prognostic factors in 1331 frozen breast cancer specimens. Cancer 1988;61:420-7.

13. Johnson TS, Williamson KD, Cramer MM, Peters LJ. Flow cytometric analysis of head and neck carcinoma DNA index and S-fraction from parafin-embedded sections: comparison with malignancy grading. Cytometry 1985;6:461-70.

14. Rew DA. Clinical applications of low cytometry. $\mathrm{Br} J$ Hosp Med 1992;48:171-5.

15. Hedley DW. Flow cytometry using parafin-embedded tissue: five years on cytometry 1989;10:229-41.

16. Begg AC, Hofland I, Moonen L, et al. The predictive value of cell kinetic measurement in European trial of accelerated fractionation in advanced head and neck carcinoma: an interim report. Int J Radiat Oncol Biol Physiol. 1990;19:144953.

17. Begg AC. Critical apraisal of insitu cell kinetic measurement as response predictors in human tumors. In: Duran RE, ed. Cell kinetic-aplications to cancer therapy. Semin Radiat Oncol 1993;3:144-51.

18. Dische S, Saunders MI, Bennet MH, Wilson GD, McNally NJ. Cell proliferation and differentiation in squamous cell cancer. Radiother Oncol 1989;5:19-23.

19. Nakano T, Oka K. Differential values of Ki-67 index and mitotic index of proliferating cell population. Cancer 1993;72:2401-8.

20. Allegranza A, Girlando S, Arrigoni GL, et al. Proliferating cell nuclear antigen expression in central nervous systems neoplasms. Virchows Arch (A) 1991;419:417-23.

21. Mc Cormick D, Hall PA. The complexities of proliferating cell nuclear antigen. Histopathology 1992;21:591-4. 